\title{
Water Productivity of Vegetables Crop under Temperate Condition of Kashmir Valley
}

\author{
Shilpa Singh ${ }^{1}$, Neeraj Singh ${ }^{2} *$ and Yogesh Pandey ${ }^{1}$ \\ ${ }^{1}$ Department of Soil and Water Engineering, COAE\&T, SKUAST-K Srinagar, India \\ ${ }^{2}$ Department of Agricultural Statistics, ANDUAT Ayodhya (UP), India \\ *Corresponding author
}

Ke y w o r d s
Water productivity,
Crop water use
efficiency,
irrigation water use
efficiency, Field
experiments

\section{A B S T R A C T}

\section{Introduction}

The world human population increasing very rapidly in the last couple of decades while the available resources for food production are being depleted due to the adverse effects of human activity on the ecosystem
(Kahramanoğlu, 2017). The crisis of water shortage increases day by day (Barlow, 2017). Water is the most valuable resource on earth (Liu et al., 2017). The total volume of water on the earth is 1.38 billion cubic kilometers (Moussa, 2018). Out of which $97.5 \%$ is salty water only $2.5 \%$ is freshwater. India contains 
$4 \%$ of the world's water resource which is about 761 cubic kilometers (Henderson, 2019). $688 \mathrm{~km}^{3}$ water is used for irrigation (Dharminder et al., 2019) and in terms of groundwater, it is approximately 70 percent (Poddar et al., 2014). On the basis of consumptive use $80-90 \%$ of all the water is consumed in agriculture (Hamdy et al., 2003). Farmers apply excess water when it is available (Jain et al., 2000). Unfortunately, water use efficiency in this sector is very poor not exceeding $45 \%$ with more than $50 \%$ water losses; thereby, the needs of present context to enhancing water productivity in the agricultural sector compared with other sector water use (Surendran et al., 2016). Total food production needs a boost for feeding a growing world population and this need to be accomplished under an increasing scarcity of water resources (Barlow and Clarke, 2017; Himanshu et al., 2019; Surendran et al., 2016). The production of more food under a water-scarce situation can be achieved by maximizing crop yield per unit of water consumption (Bouman, 2007; Kijne et al., 2003; Kumar et al., 2017), which is termed "crop water productivity" (CWP) (Molden, 1997; Kijne et al., 2003). The definition of crop water productivity can be given as the physical mass of production or the economic value of production measured against gross inflows, net inflow, depleted water, process depleted water, or available water (Molden, 1997). CWP can often be enhanced by increasing efficiency with the reduction of water losses from drainage, seepage and nonproductive evaporation.

To date, very little information is available regarding the productivity, profitability and water use efficiency (WUE) due to flood irrigation of different irrigated crops (Bhatt et al., 2019; Herath et al., 2013). WUE is important to water use indicators in the study of sustainable irrigated agriculture (Ucar et al., 2017). We can distinguish physical water productivity that is defined as the ratio of the mass of product to the amount of water consumed ('more crop per drop'). Techniques for estimating water balance range from very simple methods, such as lumped models and field-experiment techniques, to highly complex computer-based models that can calculate water balance at various temporal and spatial scales (Ghandhari and Moghaddam, 2011; Jahangeer et al., 2017). The selection of an appropriate technique depends on the objectives of the study and the availability of data (Zhang et al., 2002). Increasing a model's complexity does not necessarily improve its accuracy (Walker and Zhang, 2001), and simple lumped models may also be equally well or better than more complex alternatives (Jakeman and Hornberger, 1993). Crop models like (DSSAT, RZWQM2) are also useful for detecting suitable irrigation management and irrigation application under different climatic variables (Clothier et al., 1994; Jones et al., 2003; L. Ma et al., 2012).

Vegetable production gives economic benefits to the farmer but improper irrigation or excess use of water increases the production cost. To maximize the benefits farmers should do well-managed irrigation water practices (Guha, 2018). Studies show that there was significantly increased grain yield, evapotranspiration, and water use efficiency in the vegetable crop by using deficit irrigation as compared to rain-fed (Cantore $e t$ al., 2016; Kifle and Gebretsadikan, 2016). In order to respond to emerging crises in agricultural water management, it is ever more recommended that efforts should focus on improving water productivity (Singh., 2005; Sharma et al., 2018; Surendran et al., 2019). Hence, the purpose of the study was to evaluate the water productivity, crop water use efficiency and irrigation water use efficiency of tomato cucumber and bottle gourd crop under water stress conditions in 
northern Indian state to ensure better planning for sustainable water management. The study assesses different growth stages and identifies critical growth stages for irrigation applications for selected crops. The research output help in efficient crop-growth-stagebased deficit irrigation strategies for tomato, cucumber and bottle guard cotton under limited irrigation water availability also on changing the viewpoint of decision-makers and researchers regarding the efficient use of water resources.

\section{Materials and Methods}

\section{Study area}

The experiment was conducted at the field site in the SKUAST-K Shalimar campus which is located at $34.01^{\circ} \mathrm{N}$ latitude and $74.5^{\circ} \mathrm{E}$ longitude at an elevation of 1606 meters above the mean sea level. The SKUAST-K Shalimar campus is situated at about $15 \mathrm{Km}$ away from Srinagar (Jammu and Kashmir). The study area map is shown in (Fig 1) and the climate of the field site is of temperate type. The mean meteorological data for cropping season recorded at Meteorological Observatory, Division of Agronomy, SKUAST-Kashmir, Shalimar are presented in table 1.

\section{Experimental layout}

The field experiment was conducted to identify and categorize the stages that are most sensitive to soil moisture stress for tomato, cucumber and bottle gourd crop. The test crops were planted at the recommended planting period of the area (May 2018). The following different types of treatment strategy applied for the field experiments.

1. Check - irrigated at the optimal irrigation schedule i.e. irrigating when the total available moisture was $40 \%$ to field capacity based on FAOCROPWAT 8.

2. Dispossess irrigation water application during any of one growth stage

3. Dispossess irrigation water application during any of the two growth stages

4. Dispossess irrigation water application during any of the three growth stages

5. Dispossess irrigation water application during all growth stages

The site selected for the experiment was leveled with medium fertility status and good drainage. The soil texture of the field was found to be silty clay loam. The field for each crop was divided into 48 plots of size $6.0 \mathrm{~m} \times$ $2.0 \mathrm{~m}$, separating each plot from the adjoining plots by $30 \mathrm{~cm}$ wide small bunds, moreover, The seeds were sown by transplanting them manually in furrows. The spacing of cucumber crop, tomato, and bottle guard is $45 \times 100 \mathrm{~cm}, 35 \times 60$ and $60 \times 100$, respectively. The proper plant population was maintained and all cultural practices have been done to all treatments in accordance with the recommendation made for the area. Irrigation water was applied as per moisture content status in the upper $0-15 \mathrm{~cm}$ soil layer and stages of crop. The details about the crops and sowing and harvesting details are presented in table 2 .

The Soil moisture content before and after irrigation was monitored gravimetrically at $60 \mathrm{~cm}$ depth interval up to maximum root depth. The average bulk density $1.47 \mathrm{~g} / \mathrm{cm}^{3}$, field capacity $24 \%$ and $\mathrm{pH}$ of 7.2 was found for the soil present at the experimental field. The irrigation treatments are divided on the bases of crop growth stages. The crop growth stage divided into four different stages like Initial, developmental, midseason and crop maturity. On the bases of crop growth stages total, sixteen types of irrigation scheduling were applied at the experimental field. The details of irrigation and crop growth stage are presented in table 3 . 


\section{Irrigation scheduling}

Estimation of the potential evapotranspiration of the area is the first step to organize the irrigation schedules of the experiment. Numbers of empirical and semi-empirical formulas are used to calculate potential evapotranspiration from meteorological data (Surendran et al., 2019). "The FAO PenmanMonteith method is recommended as the standard method for the definition and computation of the reference evapotranspiration, $\mathrm{ET}_{\mathrm{o}}$ ". By using the CROPWAT 8 simulation tool developed by FAO in 2006, monthly $\mathrm{ET}_{\mathrm{o}}$ of the area was computed using minimum and maximum temperature, relative humidity, wind speed and sunshine hour data. Kc value of every crop largely depends on the crop growth stage and regional climate. The $\mathrm{Kc}$ values of tomato, cucumber and bottlegourd crops at the different stages were obtained from FAO Cropwat software. The irrigation scheduling of each treatment plot was prepared on the basis of crop water requirement (CWR) of tomato at the different stages (initial, development, mid and late-stage) of the growing period and the soil water holding capacity. The irrigation criteria were irrigating when the soil water was depleted to a critical point $(40 \%$ of total available water (TAW) for crops) which is taken from FAO CROPWAT 8, and the irrigation applied was the amount to replenish crop water use to field capacity. The net irrigation requirement was $60 \%$ of TAW multiplied the root depth at a specific growth stage. The gross irrigation can be calculated by dividing net irrigation to application efficiency.

\section{Actual Crop-Evapotranspiration (ETc) and Ke value}

The reference evapotranspiration was estimated for respective crop duration. The value of $\mathrm{Kc}$ for different crops with stage- wise was obtained from FAO drainage paper no.-56. So, ETc was calculated from following equation 1 .

$\mathrm{ETc}=\mathrm{Kc} \times \mathrm{ETo}$

Where, ETc, Actual crop-evapotranspiration (mm), Kc,crop coefficient and ETo, reference evapotranspiration $(\mathrm{mm})$.

The Kc value of different crops at different growth stages namely initial, developmental, mid-season and late-season stage are shown in Table 4 For most of the crops it is found that for the mid-season stage the $\mathrm{Kc}$ value is higher because of fully grown and maximum coverages of the ground surface.

\section{Duration of growth stages}

To find out crop coefficient $(\mathrm{Kc})$ for different crops at different growth stages, the duration of growth period must be known. The observed duration of growth was as per data provided by FAO drainage paper no-56. The observed duration of different growth stages and their length of time are given in Table 5.Figure 2 shows the different developmental stages of the selected crops.

\section{Water productivity, crop water use efficiency, and irrigation water use efficiency}

Water Productivity plays a crucial role in modern agriculture which aims to increase yield production per unit of water used, both under rainfed and irrigated conditions. Water productivity with dimensions of $\mathrm{kg} / \mathrm{m}^{3}$ is defined as the ratio of the mass of marketable yield $(\mathrm{Y})$ to the volume of water consumed by the crop (ET). Mathematically water productivity can be represented as follow in equation 2 (Ali and Talukder, 2008)

$W P=\frac{Y}{W a}$ 
Where, WP, Water productivity $\left(\mathrm{Kg} / \mathrm{m}^{3}\right)$, Y, Economic Yield $(\mathrm{kg})$ and Wa, Total Water applied $\left(\mathrm{m}^{3}\right)$.

Crop water use efficiency is mostly used to describe irrigation effectiveness in terms of crop yield (crop productivity). It is defined as the ratio of the economic yield or biological yield produced per unit of crop evapotranspiration (Odhiambo et al., 2011). The crop water use efficiency was calculated as equation 3 .

$$
C W U E=\frac{Y}{E T c}
$$

Where, CWUE, Crop water use efficiency $(\mathrm{Kg} / \mathrm{ha} / \mathrm{mm})$ and ETc, Crop evapotranspiration (ha/mm)

Irrigation water use efficiency (Eq.4) is an indices to characterize crop yield in relation to the total depth of water applied through irrigation (Odhiambo et al., 2011).

$$
I W U E=\frac{Y}{I W}
$$

Where, IWUE = Irrigation water use efficiency $(\mathrm{Kg} / \mathrm{ha} / \mathrm{mm})$ and IW, Irrigation water applied (ha/mm)

\section{Results and Discussion}

The actual rainfall recorded during the growing season was $316.4 \mathrm{~mm}$. The monthly average rainfall at the field site was presented in table 6 below. Figure 3 shows the daily recorded values of climatic variables at the field site during the cropping season. The highest temperature is recorded during the month of June of the initial stages of the vegetable crops. The rainfall was concentrated in the mid and late part of the crop growth stages. The growing season of selected vegetables varies from May to September month of the year. The daily estimated actual and reference evapotranspiration for all the selected crop was presented in figure 4 . These parameters are calculated separately for each vegetable (tomato, cucumber and bottle guard) by using vegetable specific crop coefficients. The actual evapotranspiration for tomato during the middle stage of the crop is slightly higher as compared to the cucumber and bottle guard crop.

Table7 presented the water productivity for the tomato crops were higher for the treatmentT11. In T11 irrigation water was provided at the initial and development stages only and in mid, late-season rainfall water was used up by the crop. So dispossess irrigation at mid and last stage helps to increase water productivity for the tomato crops.

Table 8 shows the regression analysis between irrigation and yield, water productivity, water use efficiency and irrigation water use efficiency for the tomato crops. Figure 5(a,b) shows the variation of actual and predictable yield of tomato against the different irrigation treatment. Trend line graph shows the $\mathrm{R}^{2}$ values 0.34 with all sets of irrigation treatment during the growing season.

Table9 shows the estimated water productivity for the cucumber crops and it was higher for the treatmentT11. In T11 irrigation water was provided at the initial and development stages only. Table 10 shows the regression analysis for the cucumber crops. Figure $6(a, b)$ shows the variation of actual and predictable yield of cucumber crops against the different irrigation treatment and trend line with applied irrigation treatment during the growing season.

Table11 presented the estimated water productivity for the bottle guard crops. The estimated water productivity was higher for 
the treatment $\mathrm{T} 11$ as tomato and cucumber crops. Table 12 shows the regression analysis for the bottle guard crops. Figure 7(a,b) shows the variation of actual and predictable yield of bottle guard against the different irrigation treatment and trend line with applied irrigation treatment during the growing season.

Table.1 Weather parameter during the period of the experiment (May -September 2018)

\begin{tabular}{|l|c|c|c|c|c|c|}
\hline Month & $\begin{array}{c}\text { Min } \\
\text { Temp }^{\circ} \mathbf{C}\end{array}$ & $\begin{array}{c}\text { Max } \\
\text { Temp }\end{array}{ }^{\mathbf{C}}$ & $\begin{array}{c}\text { Humidity } \\
\mathbf{\%}\end{array}$ & $\begin{array}{c}\text { Wind } \\
\mathbf{k m} / \mathbf{d a y}\end{array}$ & $\begin{array}{c}\text { Sunshine } \\
\text { hours }\end{array}$ & $\begin{array}{c}\text { Solar Radiation } \\
\mathbf{M J} / \mathbf{m}^{2} / \mathbf{d a y}\end{array}$ \\
\hline May & 9 & 24.6 & 61 & 46 & 7.3 & 20.6 \\
\hline June & 13.4 & 28.3 & 64 & 41 & 7.2 & 20.9 \\
\hline July & 17.2 & 28.8 & 73 & 29 & 5.7 & 18.4 \\
\hline August & 16.6 & 30.7 & 67 & 31 & 7.8 & 20.3 \\
\hline September & 11.9 & 28 & 66 & 34 & 7 & 17.1 \\
\hline
\end{tabular}

Table.2 Details of crops grown at the field site

\begin{tabular}{|l|l|l|l|l|}
\hline S.No. & Crops & Sowing date & Harvesting date & Duration (day) \\
\hline 1. & Cucumber & $25 / 05 / 2018$ & $10 / 09 / 2018$ & 105 \\
\hline 2. & Bottle guard & $25 / 05 / 2018$ & $05 / 09 / 2018$ & 100 \\
\hline 3. & Tomato & $25 / 05 / 2018$ & $10 / 09 / 2018$ & 105 \\
\hline
\end{tabular}

Table.3 Irrigation treatments details applied during the experiment

\begin{tabular}{|c|c|c|c|c|}
\hline \multirow{2}{*}{ Treatments } & \multicolumn{5}{|c|}{ Growth stages } \\
\cline { 2 - 5 } & Initial & Development & Midseason & Maturity \\
\hline T1 & 1 & 1 & 1 & 1 \\
\hline T2 & 0 & 1 & 1 & 1 \\
\hline T3 & 1 & 0 & 1 & 1 \\
\hline T4 & 1 & 1 & 0 & 1 \\
\hline T5 & 1 & 1 & 1 & 0 \\
\hline T6 & 0 & 0 & 1 & 1 \\
\hline T7 & 0 & 1 & 0 & 1 \\
\hline T8 & 0 & 1 & 0 & 0 \\
\hline T9 & 1 & 0 & 1 & 1 \\
\hline T10 & 1 & 0 & 0 & 0 \\
\hline T11 & 1 & 1 & 0 & 1 \\
\hline T12 & 0 & 0 & 1 & 0 \\
\hline T13 & 0 & 0 & 0 & 0 \\
\hline T14 & 0 & 1 & 0 & 0 \\
\hline T15 & 1 & 0 & 0 & 0 \\
\hline T16 & 0 & 0 & Note: 1 means irrigated and 0 means not irrigated during crop growth stages \\
\hline
\end{tabular}


Table.4 Kc value of selected crops for different growth stages

\begin{tabular}{|l|l|l|l|l|l|}
\hline Crops & $\begin{array}{l}\text { Duration } \\
\text { (Days) }\end{array}$ & \multicolumn{4}{l|}{ Growth stages } \\
\cline { 3 - 6 } & Initial & Development & Midseason & Late season \\
\hline Tomato & 105 & 0.6 & 0.87 & 1.15 & 0.8 \\
\hline Cucumber & 105 & 0.6 & 0.80 & 1.0 & 0.75 \\
\hline Bottle gourd & 100 & 0.6 & 0.70 & 1.0 & 0.80 \\
\hline
\end{tabular}

Table.5 Length of different growth stages of the selected crops

\begin{tabular}{|l|l|l|l|l|l|}
\hline Crops & $\begin{array}{l}\text { Duration } \\
\text { (days) }\end{array}$ & \multicolumn{2}{|l|}{ Growth stages (days) } & \\
& Initial & Development & Midseason & Late season \\
\hline Tomato & 105 & 10 & 30 & 35 & 30 \\
\hline Cucumber & 105 & 20 & 30 & 40 & 15 \\
\hline Bottle gourd & 100 & 20 & 30 & 30 & 20 \\
\hline
\end{tabular}

Table.6 The actual rainfall during the growing period

\begin{tabular}{|c|c|}
\hline Month & Actual rain fall $(\mathbf{m m} / \mathbf{m o n t h})$ \\
\hline May & 0 \\
\hline June & 61.6 \\
\hline July & 134.2 \\
\hline Aug & 120.6 \\
\hline Total & 316.4 \\
\hline
\end{tabular}

Table.7 Water productivity and related components of irrigation waterfor tomato crop

\begin{tabular}{|c|c|c|c|c|}
\hline $\begin{array}{c}\text { Treatment } \\
\text { No }\end{array}$ & $\begin{array}{c}\text { Yield } \\
\text { (ton /ha) }\end{array}$ & $\begin{array}{c}\text { Total } \\
\text { water }\left(\mathbf{m}^{\mathbf{3}} \mathbf{h a}\right)\end{array}$ & $\begin{array}{c}\text { Water } \\
\text { productivity } \\
\left(\mathbf{k g} / \mathbf{m}^{\mathbf{3}}\right)\end{array}$ & $\begin{array}{c}\text { Rank } \\
\text { for yield }\end{array}$ \\
\hline T1 & 39.31 & 5890 & 6.67 & 4 \\
\hline T2 & 28.6 & 4960.32 & 5.77 & 11 \\
\hline T3 & 34.51 & 5227.76 & 6.60 & 6 \\
\hline T4 & 40.7 & 5385.1 & 7.56 & 3 \\
\hline T5 & 43.2 & 5290.72 & 8.17 & 13 \\
\hline T6 & 21.78 & 4110.6 & 5.30 & 8 \\
\hline T8 & 33.54 & 4589 & 7.31 & 9 \\
\hline T9 & 31.32 & 4430.82 & 7.07 & 5 \\
\hline T10 & 36.19 & 3360.12 & 10.77 & 2 \\
\hline T11 & 44.21 & 3570.61 & 9.58 & 15 \\
\hline T13 & 41.69 & 3100 & 13.45 & 14 \\
\hline T14 & 20.13 & 2785 & 6.77 & 10 \\
\hline T15 & 29.81 & 2785 & 7.23 & 12 \\
\hline T16 & 24.3 & 2785 & 10.70 & 16 \\
\hline
\end{tabular}


Table.8 The regression relationship between irrigation and yield, water productivity (WP), crop water use efficiency (CWUE) and irrigation water use efficiency (IWUE) in tomato crop

\begin{tabular}{|c|c|c|c|}
\hline Dependent variable & Regression equation & $\mathbf{R}^{\mathbf{2}}$ & $\mathbf{P}$ \\
\hline Yield & $\mathrm{Y}=12.35+0.004 \mathrm{X}$ & 0.50 & 0.0023 \\
\hline WP & $\mathrm{Y}=13.28-0.001 \mathrm{X}$ & 0.44 & 0.0048 \\
\hline CWUE & $\mathrm{Y}=37.16+0.013 \mathrm{X}$ & 0.49 & 0.0024 \\
\hline IWUE & $\mathrm{Y}=194.62+0.011 \mathrm{X}$ & 0.04 & 0.4410 \\
\hline \multicolumn{2}{|l}{$\boldsymbol{R}^{\mathbf{2}}$ - coefficient of determination; $\boldsymbol{P}$ - statistically significant value } \\
\hline
\end{tabular}

Table.9 Water productivity and related components of irrigation water forCucumber crop

\begin{tabular}{|c|c|c|c|c|}
\hline Treatment No & Yield (ton /ha) & $\begin{array}{c}\text { Total water } \\
\left(\mathrm{m}^{3} / \mathrm{ha}\right)\end{array}$ & $\begin{array}{c}\text { Water productivity } \\
\left(\mathrm{kg} / \mathrm{m}^{3}\right)\end{array}$ & $\begin{array}{c}\text { Rank for } \\
\text { yield }\end{array}$ \\
\hline T1 & 28.31 & 3431.2 & 8.25 & 1 \\
\hline $\mathbf{T 2}$ & 16.89 & 2563.87 & 6.59 & 11 \\
\hline T3 & 18.71 & 2841.23 & 6.59 & 7 \\
\hline T4 & 26.11 & 2918.4 & 8.95 & 4 \\
\hline T5 & 28.31 & 2880.11 & 9.83 & 1 \\
\hline T6 & 14.97 & 1774.92 & 8.43 & 13 \\
\hline T7 & 17.56 & 2380 & 7.38 & 8 \\
\hline T8 & 16.95 & 2257.76 & 7.51 & 10 \\
\hline T9 & 20.22 & 1283.97 & 15.75 & 5 \\
\hline T10 & 18.73 & 1405.34 & 13.33 & 6 \\
\hline T11 & 26.96 & 1397.45 & 19.29 & 3 \\
\hline T12 & 9.37 & 1180.65 & 7.94 & 15 \\
\hline T13 & 10.86 & 1067.72 & 10.17 & 14 \\
\hline T14 & 17.17 & 1396.9 & 12.29 & 9 \\
\hline T15 & 15.1 & 1287.43 & 11.73 & 12 \\
\hline T16 & 8.36 & 576.71 & 14.50 & 16 \\
\hline
\end{tabular}

Table.10 The regression relationship between irrigation and yield, water productivity (WP), crop water use efficiency (CWUE) and irrigation water use efficiency (IWUE) in cucumber crop

\begin{tabular}{|c|c|c|c|}
\hline Dependent variable & Regression equation & $\mathbf{R}^{2}$ & $\mathbf{P}$ \\
\hline Yield & $\mathrm{Y}=8.45+0.005 \mathrm{X}$ & 0.47 & 0.0032 \\
\hline WP & $\mathrm{Y}=15.67-0.002 \mathrm{X}$ & 0.37 & 0.0117 \\
\hline CWUE & $\mathrm{Y}=25.33+0.014 \mathrm{X}$ & 0.46 & 0.0040 \\
\hline IWUE & $\mathrm{Y}=180.32+0.011 \mathrm{X}$ & 0.02 & 0.6263 \\
\hline
\end{tabular}


Table.11 Water productivity and related components of irrigation water for Bottle gourd crop

\begin{tabular}{|c|c|c|c|c|}
\hline $\begin{array}{c}\text { Treatment } \\
\text { No }\end{array}$ & $\begin{array}{c}\text { Yield } \\
\text { (ton } / \mathbf{h a})\end{array}$ & $\begin{array}{c}\text { Total water } \\
\left(\mathbf{m}^{\mathbf{3}} \mathbf{\text { ha }}\right)\end{array}$ & $\begin{array}{c}\text { Water productivity } \\
\left(\mathbf{k g} / \mathbf{m}^{\mathbf{3}}\right)\end{array}$ & $\begin{array}{c}\text { Rank for } \\
\text { yield }\end{array}$ \\
\hline $\mathbf{T 1}$ & 33.60 & 3660.00 & 9.18 & 1 \\
\hline T2 & 18.35 & 2784.78 & 6.59 & 10 \\
\hline T3 & 21.32 & 3090.15 & 6.90 & 7 \\
\hline T4 & 32.00 & 3138.90 & 10.19 & 2 \\
\hline T5 & 30.98 & 3100.10 & 9.99 & 4 \\
\hline T6 & 15.50 & 2260.20 & 6.86 & 11 \\
\hline T7 & 20.87 & 2478.93 & 8.42 & 8 \\
\hline T8 & 19.90 & 2320.80 & 8.57 & 9 \\
\hline T9 & 24.85 & 1560.10 & 15.93 & 5 \\
\hline T10 & 21.79 & 1700.00 & 12.82 & 3 \\
\hline T11 & 31.55 & 1367.32 & 23.07 & 15 \\
\hline T12 & 6.70 & 900.43 & 7.44 & 13 \\
\hline T13 & 7.21 & 850.65 & 8.48 & 12 \\
\hline T14 & 9.38 & 870.10 & 10.78 & 16 \\
\hline T15 & 7.10 & 760.80 & 9.33 & \\
\hline T16 & 5.30 & 440.30 & 12.04 & \\
\hline
\end{tabular}

Table.12 The regression relationship between irrigation and yield, water productivity (WP), crop water use efficiency (CWUE) and irrigation water use efficiency (IWUE) for bottle gourd crop

\begin{tabular}{|l|l|l|c|}
\hline Dependent variable & Regression equation & \multicolumn{1}{c|}{$\mathbf{R}^{\mathbf{2}}$} & $\mathbf{P}$ \\
\hline Yield & $\mathrm{Y}=4.72+0.007 \mathrm{X}$ & 0.59 & 0.0004 \\
\hline WP & $\mathrm{Y}=12.79-0.001 \mathrm{X}$ & 0.09 & 0.2590 \\
\hline CWUE & $\mathrm{Y}=16.83+0.022 \mathrm{X}$ & 0.58 & 0.0006 \\
\hline IWUE & $\mathrm{Y}=84.23+0.036 \mathrm{X}$ & 0.30 & 0.0271 \\
\hline
\end{tabular}

Figure.1 The location map of the experimental field site

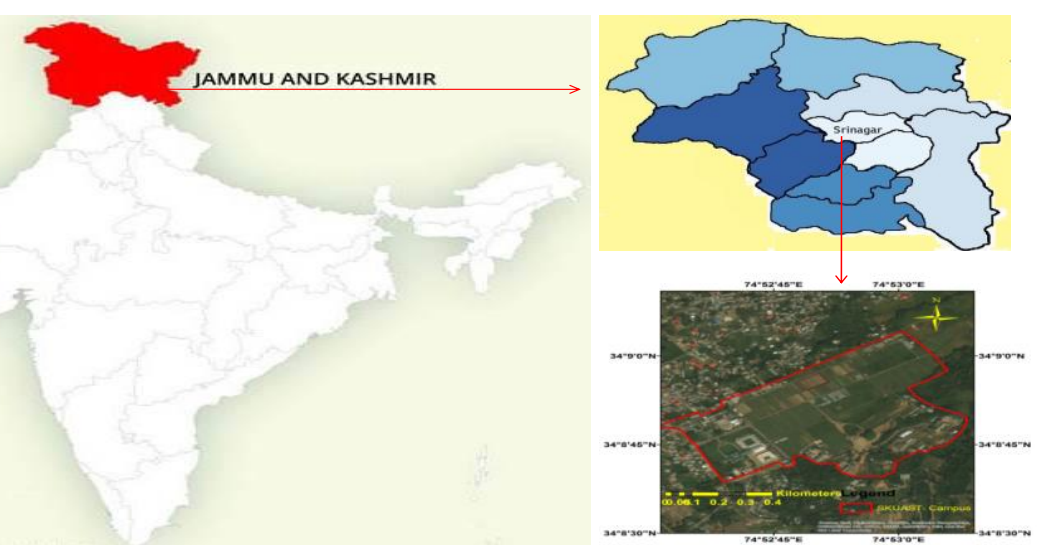


Figure.2 Different growth stages of selected vegetable crops

Initial stage
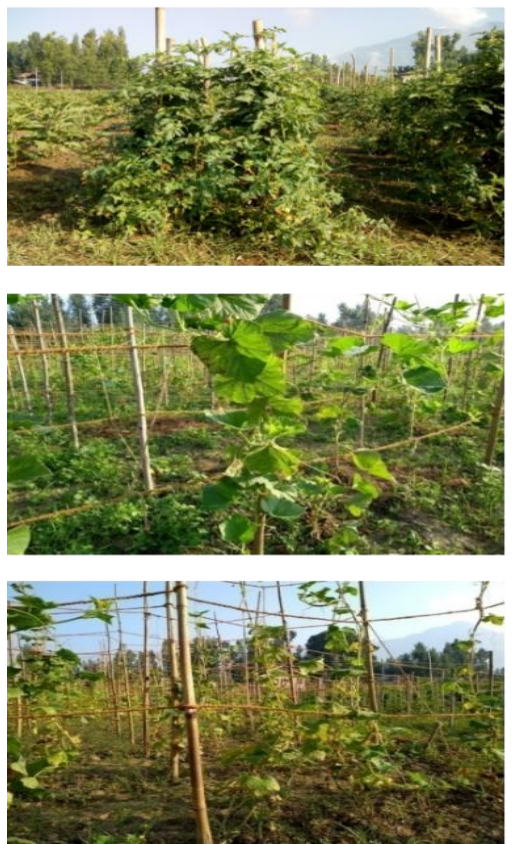

Mid season stage
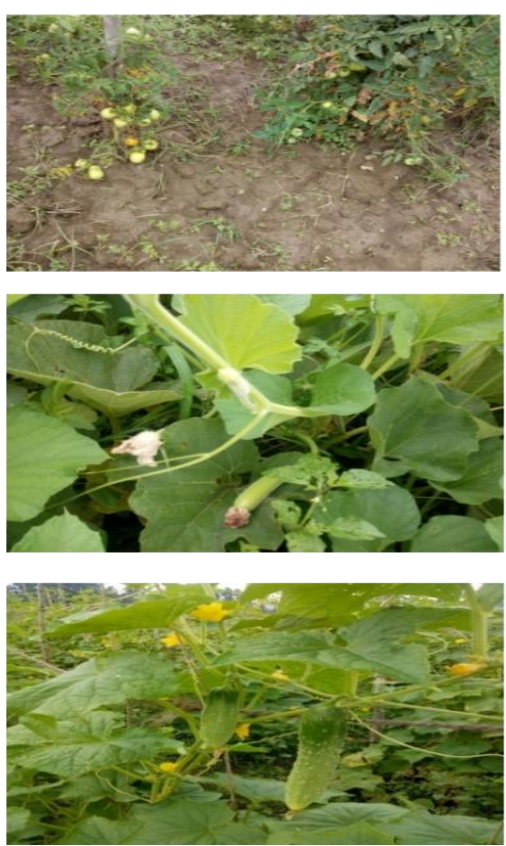

End season stage
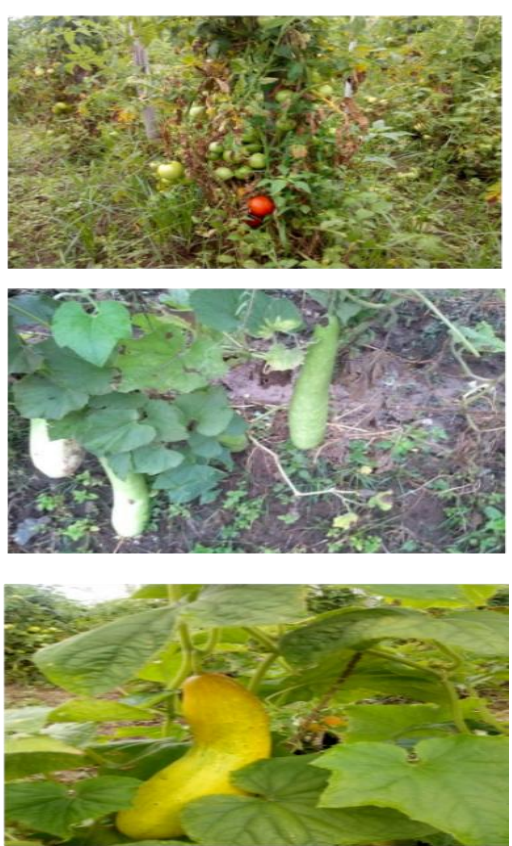

Figure.3 Daily measured rain events, evaporation, the maximum and minimum temperature during the cropping season of the selected crops at the field sites.

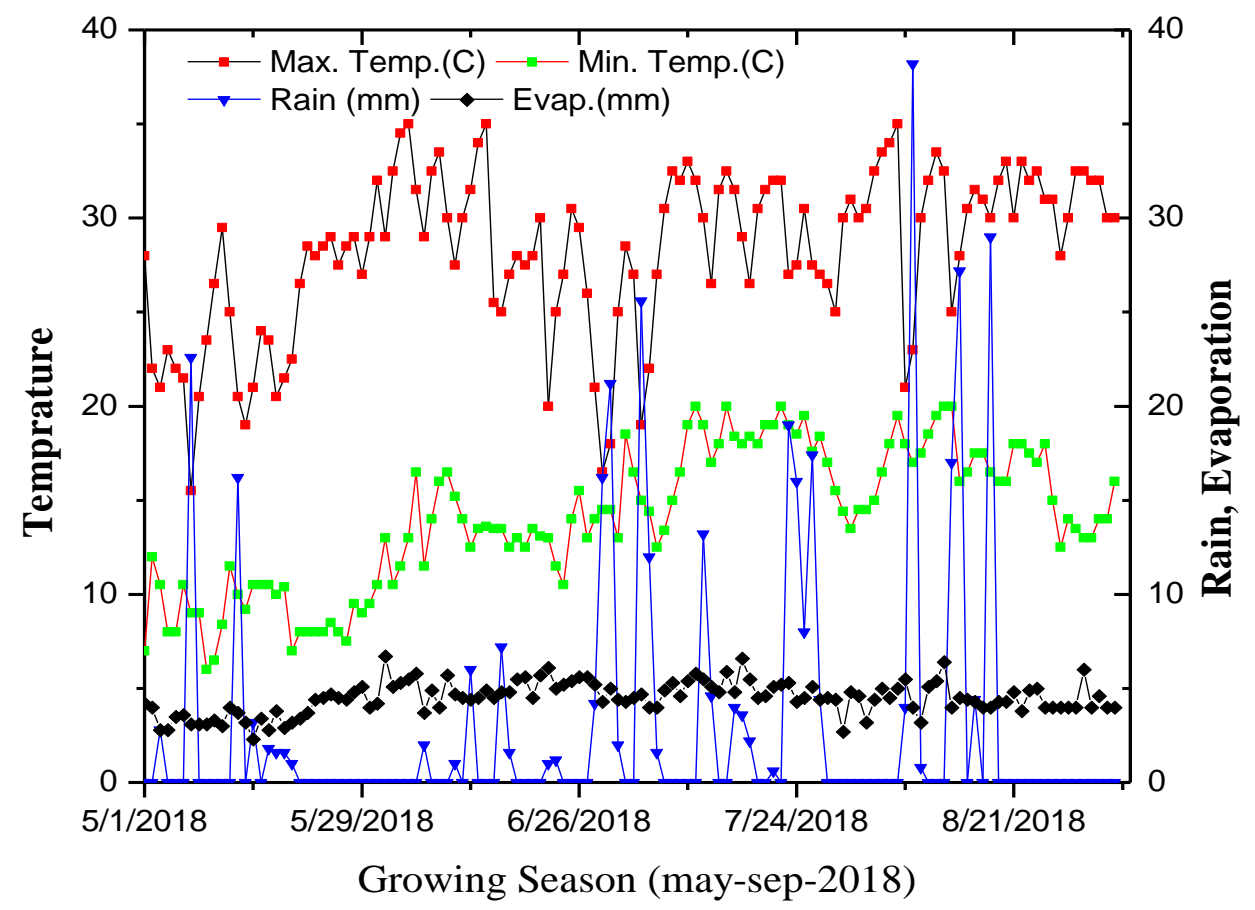


Figure.4 Daily estimated $\mathrm{ET}_{\mathrm{c}}$ and $\mathrm{ET}_{0}$ for the selected crop during $25^{\text {th }}$ May $-10^{\text {th }} \mathrm{Sep} 2018$ (a) Tomato, (b) Cucumber and (c) Bottle gourd

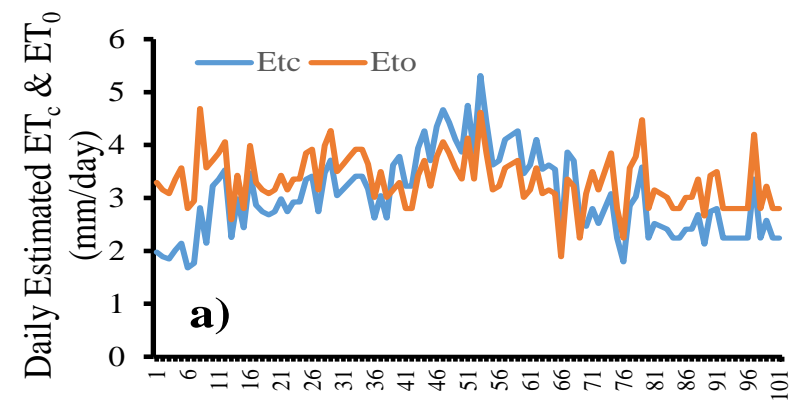

Day after sowing

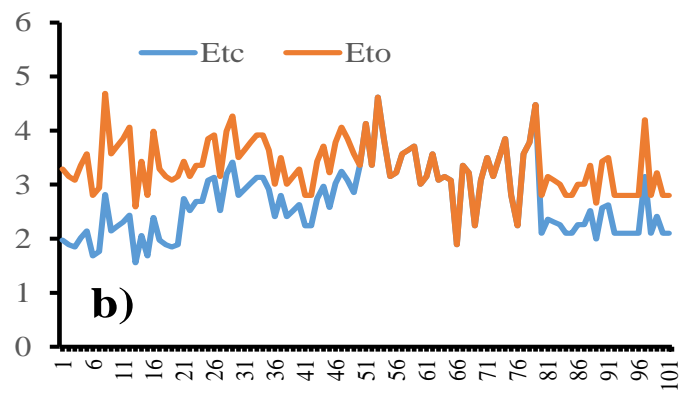

Day after sowing

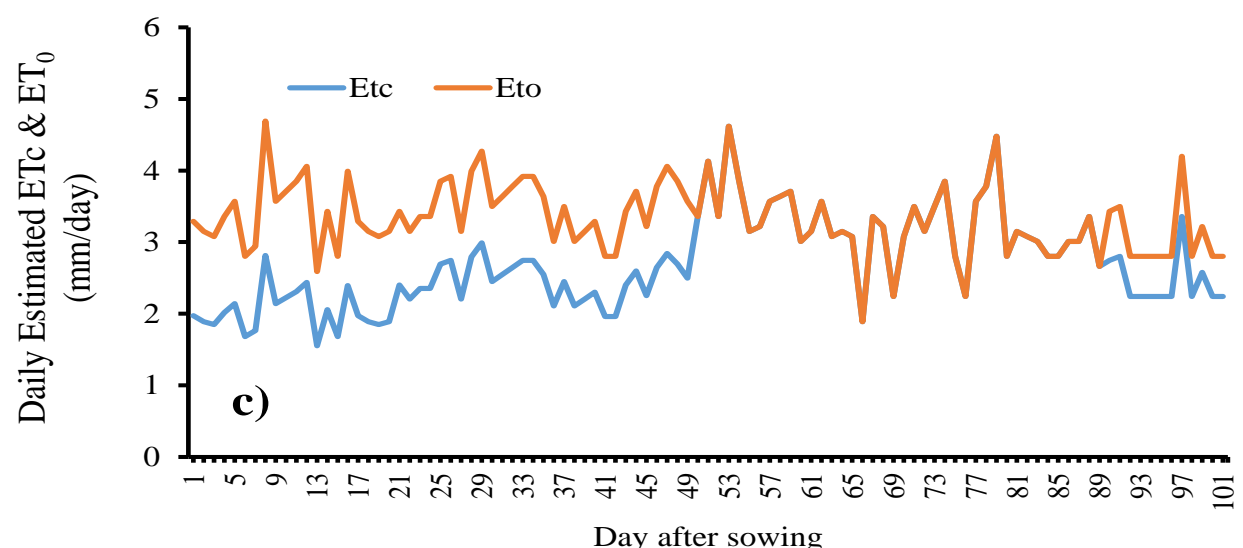

Figure.5 Actual and predictable yield in tomato crop (a) Trend line showing the relationship between water and yield of tomato crop (b).
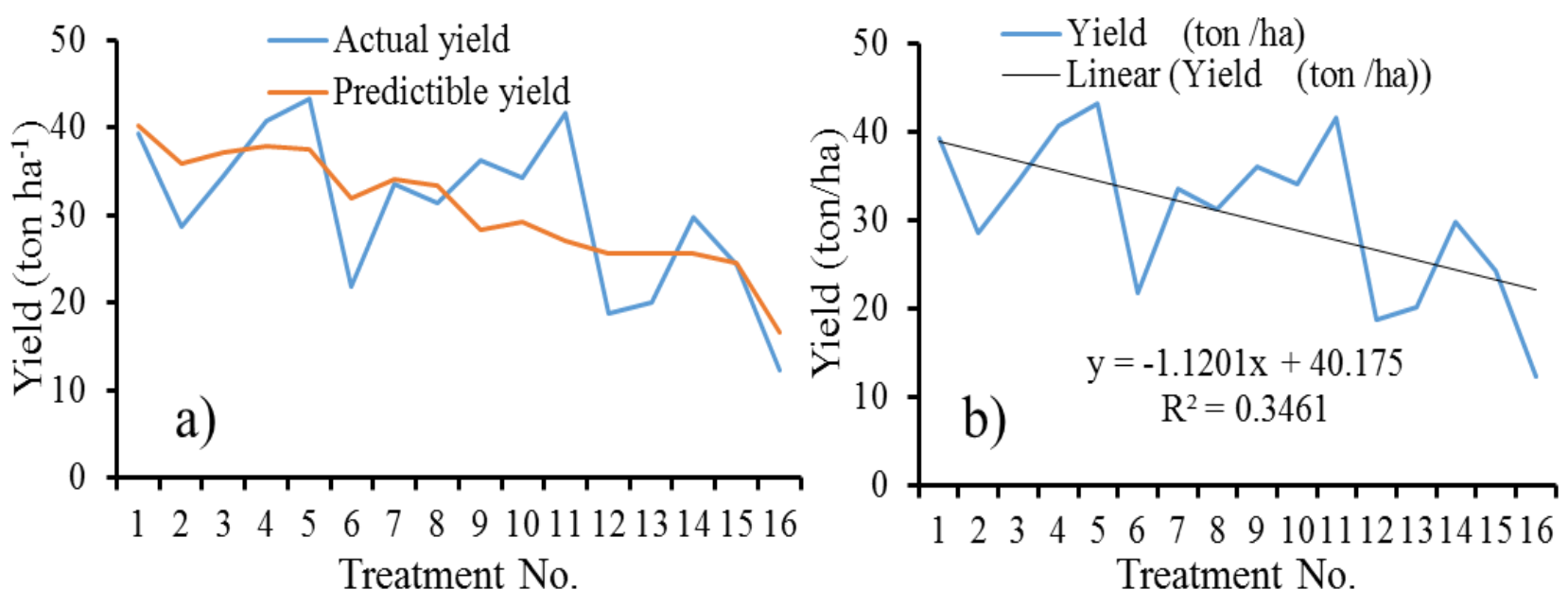
Figure.6 Actual and predictable yield in cucumber crop (a) Trend line showing the relationship between water and yield of cucumber crop (b).
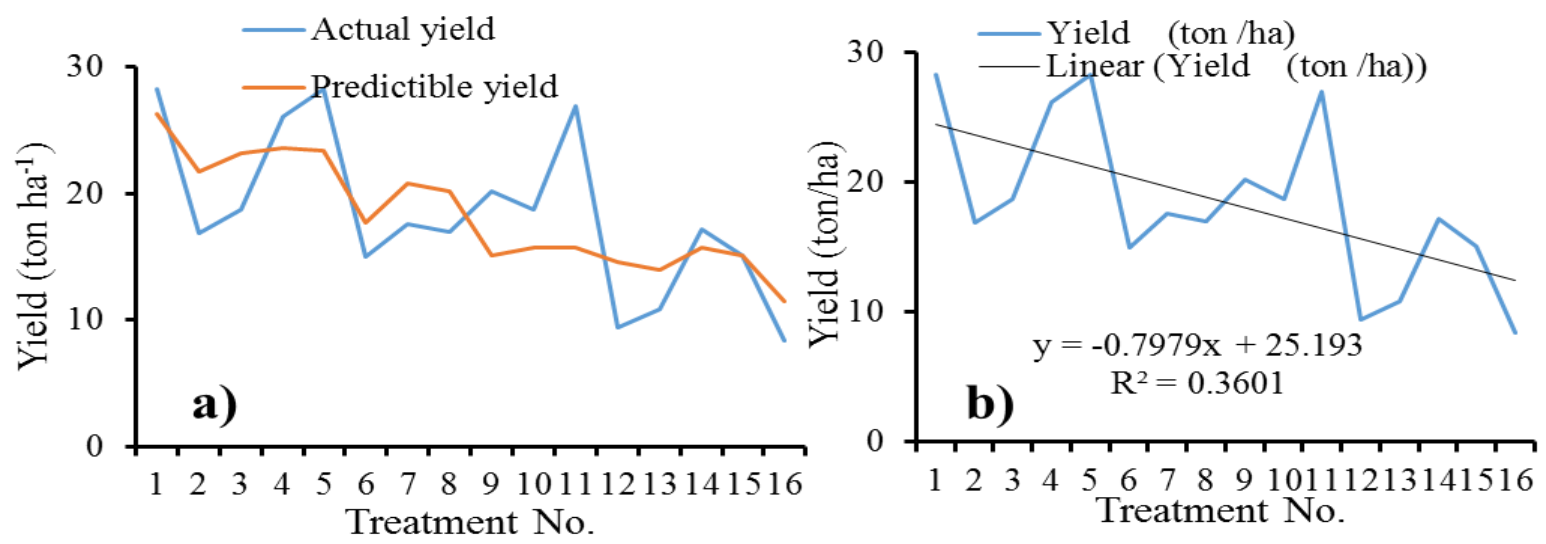

Figure.7 Actual and predictable yield in bottle guard crop (a) Trend line showing the relationship between water and yield of bottle guard crop (b).
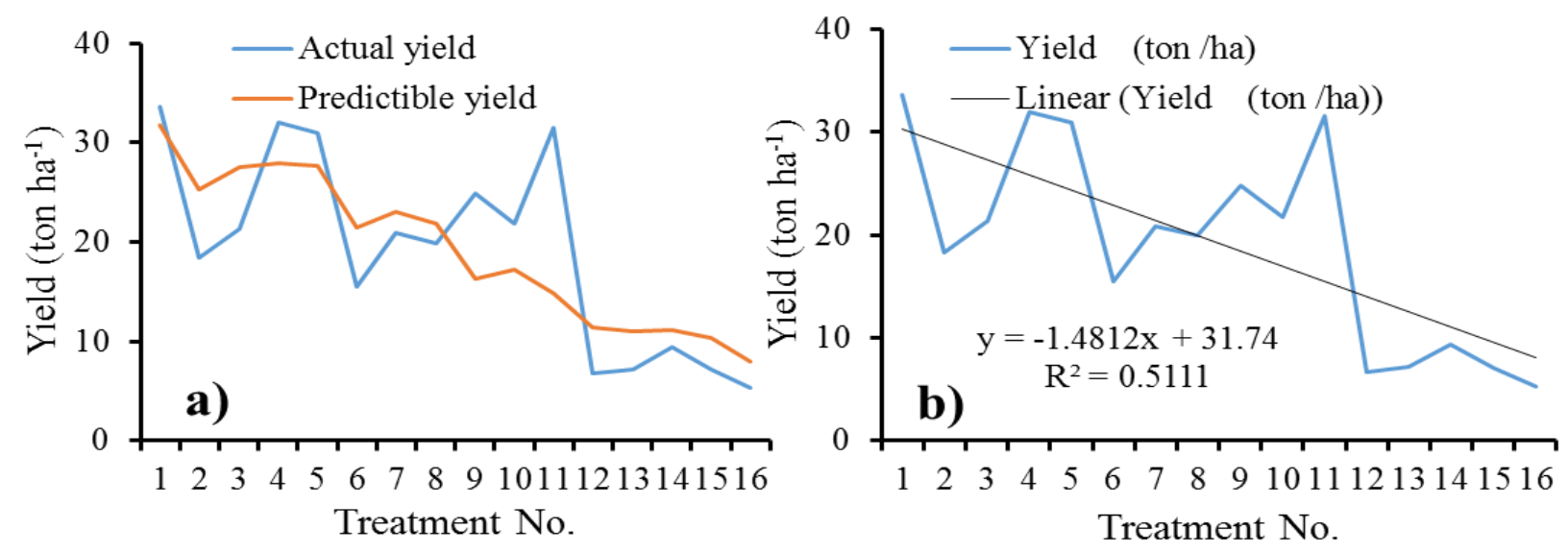

Fig.8 CWUE of bottle gourd, cucumber, and tomato

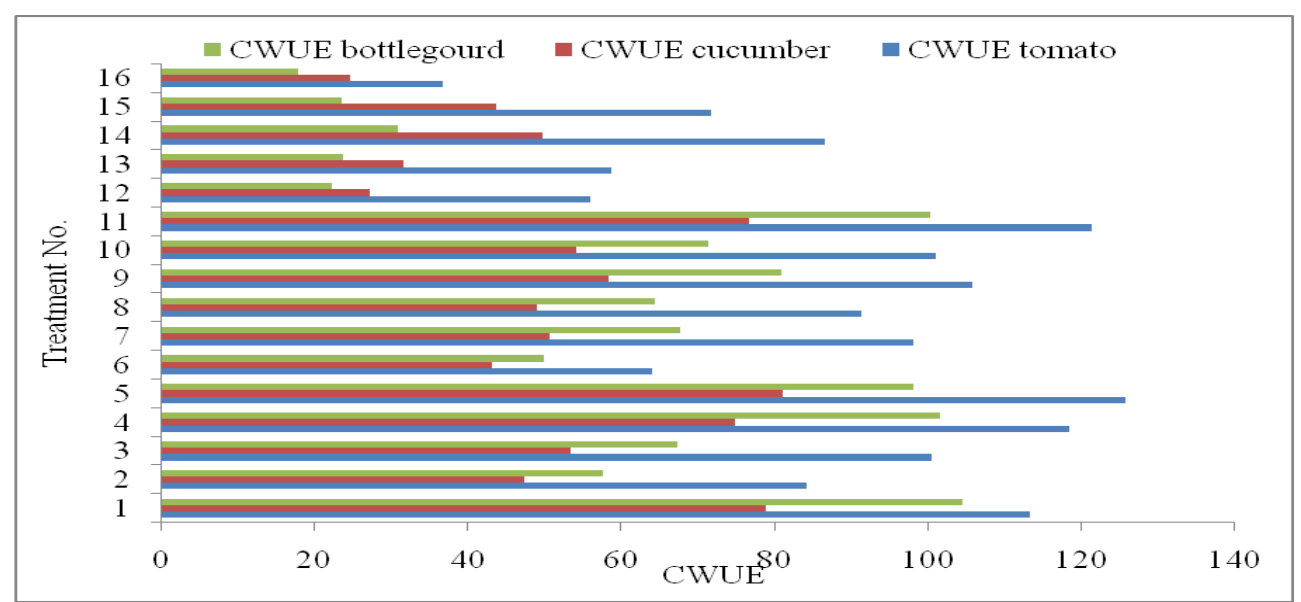


Fig.9 IWUE of bottle gourd, cucumber, and tomato

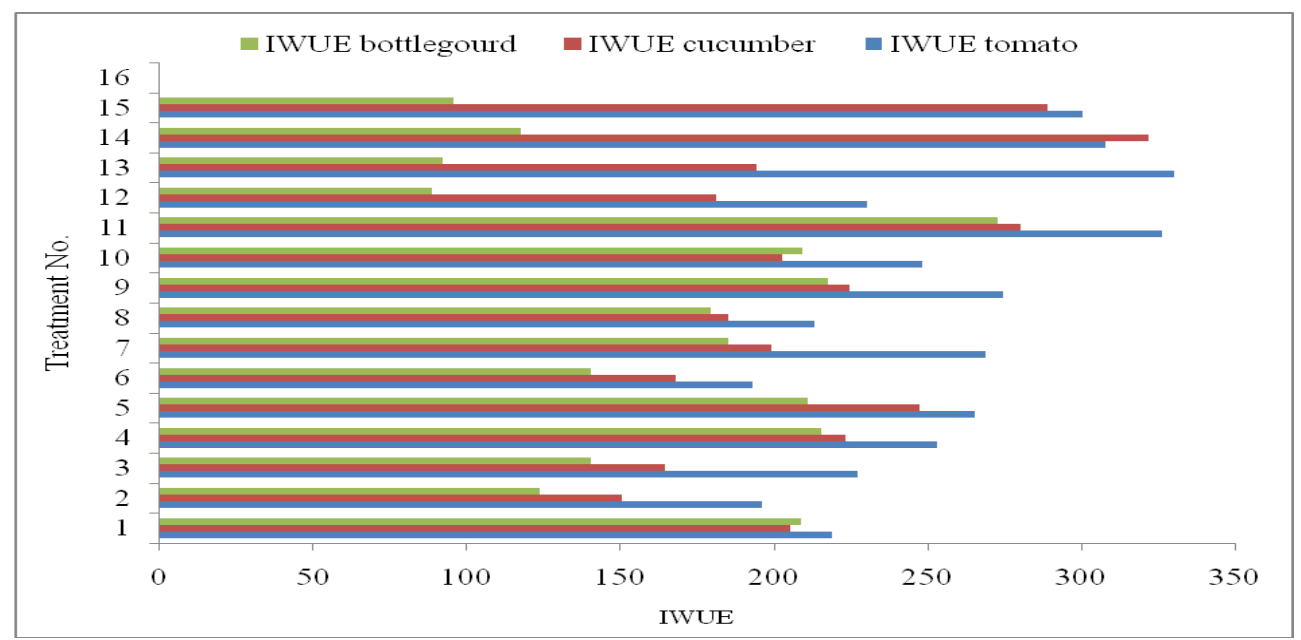

Irrigation treatment $\mathrm{T} 11$ shows the higher water productivity for the all selected crops. In this irrigation treatment irrigation was applied at the initial and development stages of the crops. The crop needed more water in the initial and development growth stage. During the mid and late-stages crops used rainfall for their growth hence no need for irrigation at these stages.

Figure 8 represented the CWUE (kg/ha/mm) for all crops with applied irrigation treatments and it were in the range of 36.59-125.37, 24.53-80.96 and 17.79-101.53 for tomato, cucumber, and bottle gourd crop. The lowest CWUE obtained in treatment 16 because it totally depends on the rainfall. Zero irrigation was given to T16, therefore, the total yield for this treatment was very low. Similarly, fig 9 shows the IWUE of tomato, cucumber and bottle gourd crop with applied different irrigation treatments.

For tomato, cucumber and bottle gourd crop treatment 1 (T1) is with full irrigation in all stages, based on the crop water demand to relate with the stress at the different growth stages. There is no significant difference in yield between irrigating all growth stages and only the first two stages because of considerable rainfall contribution at a mid and late stage. The average yield of tomato, cucumber and bottlegourd was 30.65 ton/ha, 18.41 ton/ha and 19.15 ton/ha. The maximum and minimum yield for the tomato was 43.2 ton/ha and 12.31 ton/ha. The range of water productivity for tomato crop was 5.3 $13.45 \mathrm{~kg} / \mathrm{m}^{3}$. A similar result was also found by Singh et al., (2010) and Jha et al.,(2017). Crop water use efficiency varies from 36.59 $125.65 \mathrm{~kg} / \mathrm{ha} / \mathrm{mm}$ for tomato crops. Zeng et al., (2009) support our results and report showing that major irrigation water deficiencies led to greater WUE, but to lower yields. The highest irrigation water use efficiency was $325.7 \mathrm{~kg} / \mathrm{ha} / \mathrm{mm}$ for $\mathrm{T} 11$ in tomato crops. Similar findings have been accounted for by Rashidi et al., (2008). The main factor responsible for lower water productivity in treatment 6 was due to higher amount of irrigation water applied in comparison to actual need, at mid and latestage neglecting the effect of texture, while in treatment 11 was found higher productivity because the yield of tomato is higher at lower use of water.

WANG et al., (2007) found no significant differences for tomato yield under different soil water potentials. Treatment 11 and 
treatment 16 shows almost equal water productivity in tomato crops but with a large difference in yield. Better water productivity means a reasonable yield with moderate use of water. Similarly, range of water productivity and crop water use efficiency for cucumber crops found to be 6.59 to 15.75 $\mathrm{kg} / \mathrm{m}^{3}$ and 24.53 to $80.96 \mathrm{~kg} / \mathrm{ha} / \mathrm{mm}$. These results are also in agreement with (Yaghi et al., 2013). (Oliveira et al., 2011) supports our results conclude that WUE reflects the conversion rate of the fruit, i.e., the amount of fresh matter produced by each unit of water applied. Thus, the concept of WUE is relative, i.e., a greater efficiency does not correspond to increased yield. Similarly, (Dermitas and Ayas, 2009) established that the cucumber plant showed higher WUE values for lower water stress rates. Thus, improved WUE may be achieved by reducing the water supply. However, excessive reduction of irrigation reduced the crop yields (Li et al., 2017a).

The highest irrigation water use efficiency for cucumber crop was found in T14 (321.48 $\mathrm{kg} / \mathrm{ha} / \mathrm{mm}$ ). For bottle gourd crop maximum water productivity $\left(15.93 \mathrm{~kg} / \mathrm{m}^{3}\right)$ found in $\mathrm{T} 9$ and highest irrigation water use efficiency $(272.43 \mathrm{~kg} / \mathrm{ha} / \mathrm{mm})$ in treatment 11 . The same result was founded by (Shatoury et al., 2014), Rosin et al., (2017).

By irrigating only the first two stages means the average harvested yield of $\mathrm{T} 4, \mathrm{~T} 5$ and $\mathrm{T} 11$ was 41.86 ton/ha, 27.12 ton/ha and 31.51 ton/ha for tomato, cucumber and bottle gourd crop respectively. With this rainfall condition, either irrigation or no irrigation in the late and mid-stage didn't show any significant difference in yield.

Table 7, 8 and 9 shows the yield and water productivity for different irrigation scheduling, this helps the farmers to choose the best combination based on the water availability, the irrigated area.
Taking the input amount of water as the independent variable and defining the yield, WP, CWUE and IWUE as the dependent variables, then, regression analysis was conducted (Table 8, Table 10 and Table 12) for tomato, cucumber and bottle gourd crop. Results showed that the effects of irrigation amount on each dependent variable were significant $(P<0.05)$. Water use efficiency can be increased by two means, either by increasing yield by genetic manipulation, developing high genetically potential variety which is a task of life science or as a water conservator, reduction in evaporation and reduction in transpiration rate up to maximum extent that would not deter to crop production, increasing water holding capacity, reduction in runoff and percolation losses could of immense significance.

In conclusion, within the scenarios of water scarcity, the concept of water productivity plays a strategic role in the sustainability of water resources. The increasing water scarcity and mismanagement of the available water resources are nowadays major threats to sustainable development for the various sectors, especially domestic, industrial and agricultural. This experiment was carried out aiming at improving water productivity and water use efficiency of tomato, cucumber and bottle gourd crop for the temperate condition of Kashmir. The experiment stressed vegetable crops at different growth stages to identify its sensitivity to water stress at different growth stages, the critical time for irrigation application in the case of limited water resources and the level of water productivity under water-stressed conditions. The initial and development stage of vegetables needs more water than the mid and end-stage (Studer and Spoehel, 2019). So by providing limited water to the mid and endstage, water can be saved significantly, hence water productivity also increases. 


\section{References}

Ali, M. H. and Talukder, M. S. U. 2008. Increasing water productivity in crop production a synthesis. Agricultural Water Management 95(11): 1201-1213.

Barlow, M., and Clarke, T. (2017). Blue gold: the battle against corporate theft of the world's water. Routledge.

Barlow, M., and Clarke, T. (2017). Blue gold: the battle against corporate theft of the world's water. Routledge.

Bhatt, R., Hossain, A., and Hasanuzzaman, M. (2019). Adaptation Strategies to Mitigate the Evapotranspiration for Sustainable Crop Production: A Perspective of RiceWheat Cropping System. In Agronomic Crops (pp. 559-581). Springer, Singapore

Bouman, B. A. M., Peng, S., Castaneda, A. R. and Visperas, R. M. 2007. Yield and water use of irrigated tropical aerobic rice systems. Agricultural Water Management, 74(2): 87-105.

Cantore, V., Lechkar, O., Karabulut, E., Sellami, M. H., Albrizio, R., Boari, F., ... and Todorovic, M. (2016). Combined effect of deficit irrigation and strobilurin application on yield, fruit quality and water use efficiency of "cherry" tomato (Solanum lycopersicum L.). Agricultural Water Management, 167, 53-61.

Clothier, B. E. and Green, S. R. 1994. Rootzone processes and the efficient use of irrigation water. Agricultural Water Management, 25(1), 1-12.

Dermitas, C.; Ayas, S. Deficit irrigation effects on pepper (Capsicum annuum L. Demre) yield in unheated greenhouse condition. Journal of Food, Agricultural and Environment, Helsinki, v.7, n.3-4, p.9891003, 2009.

Dharminder, R. K. S., Kumar, V., Devedee, A. K., Mruthyunjaya, M., and Bhardwaj, R. (2019). The clean water: The basic need of human and agriculture. IJCS, 7(2), 1994-1998

Ghandhari, A., Alavi moghaddam. and S. M. R. 2011. Water balance principles: a review of five watershed in Iran. J. Environment
Science Technology. 4 (5): 465-479.

Guha, R. K. (2018). HAPA: Dreaming with small pond. In Conference on "Rural India: Blossoming in Neglect.

Hamdy, A., Ragab, R., and ScarasciaMugnozza, E. 2003. Coping with water scarcity: water saving and increasing water productivity. Irrigation and Drainage: The journal of the International Commission on Irrigation and Drainage, 52(1), 3-20.

Henderson, J. C. (2019). Wastewater Effluent Transport and Contamination: A Model for Groundwater Contamination in the Central West Bank. Drexel University.

Herath, I., Green, S., Horne, D., Singh, R., McLaren, S., and Clothier, B. 2013. Water footprinting of agricultural products: evaluation of different protocols using a case study of New Zealand wine. Journal of cleaner production, 44, 159167.

Himanshu, S. K., Ale, S., Bordovsky, J., andDarapuneni, M. (2019). Evaluation of crop-growth-stage-based deficit irrigation strategies for cotton production in the Southern High Plains. Agricultural Water Management, 225, 105782.

Jahangeer, Gupta, P. K., and Yadav, B. K. (2017). Transient water flow and nitrate movement simulation in partially saturated zone. Journal of Irrigation and Drainage Engineering, 143(12), 04017048.

Jain, N., Chauhan, H.S., Singh, P.K., Shukla, K.N., 2000. Response of tomato under drip irrigation and plastic mulching. In: Proceeding of 6th International Microirrigation Congress, Microirrigation Technology for Developing Agriculture, 22-27 October 2000, South Africa.

Jakeman, A.J. and Hornberger, G.M. 1993. How much complexity is warranted in a rainfall runoff model. Water Resource Research29: 2537-2649.

Jha, B. K., Mali, S. S., Naik, S. K. and Sengupta, T. 2017. Yeild, water productivity and economics of vegetable 
production under drip and furrow irrigation in eastern plateau and hill region of India. International Journal of Agricultural Sciences and Research, 7(3):43-50.

Jones, J. W., Hoogenboom, G., Porter, C. H., Boote, K. J., Batchelor, W. D., Hunt, L. A., ... and Ritchie, J. T. (2003). The DSSAT cropping system model. European journal of agronomy, 18(3-4), 235-265.

Kahramanoğlu, İ. (2017). Introductory chapter: Postharvest physiology and technology of horticultural crops. InTech Open: London, UK, 1-5.

Kifle, M., and Gebretsadikan, T. G. (2016). Yield and water use efficiency of furrow irrigated potato under regulated deficit irrigation, Atsibi-Wemberta, North Ethiopia. Agricultural water management, 170, 133-139.

Kijne, J. W., T. P. Tuong, J. Bennett, B. Bouman and T. Oweis. 2003. Ensuring food security via improvement in crop water productivity. In: ChallengeProgram on Water and Food: Background Papers to the FullProposal. Colombo, Sri Lanka The Challenge Program on Water and Food Consortium.

Kumar, A., Nayak, A. K., Sah, R. P., Sanghamitra, P., and Das, B. S. 2017. Effects of elevated $\mathrm{CO} 2$ concentration on water productivity and antioxidant enzyme activities of rice (Oryza sativa $\mathrm{L}$.) under water deficit stress. Field Crops Research, 212, 61-72.

Li J.M., Fan X.Y., Yan F.F., Li H., Cai D.S. (2017a): Effect of different irrigation amount based on transpiration model on yield and quality of muskmelon. Transactions of the Chinese Society of Agricultural Engineering, 33: 156-162.

Liu, J., Yang, H., Gosling, S. N., Kummu, M., Flörke, M., Pfister, S., ... and Alcamo, J. 2017. Water scarcity assessments in the past, present, and future. Earth's future, 5(6), 545-559.

Ma, L., Trout, T. J., Ahuja, L. R., Bausch, W. C., Saseendran, S. A., Malone, R. W., and
Nielsen, D. C. (2012). Calibrating RZWQM2 model for maize responses to deficit irrigation. Agricultural water management, 103, 140-149.

Molden, D. 1997. Accounting for Water Use and Productivity, SWIM Paper, International Irrigation Management Institute, Colombo, Sri Lanka1:16.

Moussa, A. M. A. (2018). Assessment of Sediment Deposition in Aswan High Dam Reservoir During 50 Years (1964-2014). In Grand Ethiopian Renaissance Dam Versus Aswan High Dam (pp. 233-253). Springer, Cham.

Odhiambo OL, Eisenhauer, Dean E., 2011. "Irrigation efficiency and uniformity, and crop water use efficiency." The Board of Regents of the University of NebraskaLincoln Extension.

Oliveira. E. C., Carvalho. E. C. J. D., Silva. W. G. D., Rezende. F. C. and Almeida. W.F.D. 2011. Effects of Water Deficit in Two Phenological Stages on Production of Japanese Cucumber Cultived in Greenhouse. Eng. Agríc., Jaboticabal, v.31, n.4, p.676-686, jul./ago.

Poddar, R., Qureshi, M.E. and Shi, T. 2014. A comparison of water policies for sustainable irrigation management: the case of India and Australia. Water Resources Management28(4):1079.

Rashidi, M. and Gholami, M., 2008. Review of crop water productivity values for Tomato, potato, melon, watermelon and cantaloupe in Iran. International Journal of Agriculture and Biology 10:4.

Rosin, K. G., Kaur, R., Patel, N., Rajput, T. B. S. and Kumar, S. 2017. Yeild and irrigation water use efficiency of bottle gourd (Lagenaria sicenaria L.) in response to different irrigation methods and planting geometries. International Journal of Current Microbiology and Applied Sciences 6(5): 2475-2481.

Sharma, B. R., Gulati, A., Mohan, G., Manchanda, S., Ray, I., and Amarasinghe, U. (2018). Water productivity mapping of major Indian crops.

Shatoury. R.S.E. and Mahmoud. A.K. 2014. 
Mathematical Relationship for Influencing Amount of Water and Plant Distance on Bottle Gourd Plant Production. IOSR Journal of Agriculture and Veterinary Science, Volume 7, Issue 11 Ver. III, PP 29-33.

Singh, R. 2005. Water productivity analysis from field to regional scale: integration of soil and crop modeling, remote sensing and geographical information. (Doctoral dissertation, $\mathrm{PhD}$ thesis, Wageningen University, Wageningen, the Netherlands).

Singh, Ravender.,Kundu, D. K. and Bandyopadhyay, K. K. 2010. Enhancing agricultural productivity through enhanced water use efficiency. Journal of Agricultural Physics, 10:1-15.

Studer, C., and Spoehel, S.(2019). Potential and Actual Water Savings through Improved Irrigation Scheduling in Small-Scale Vegetable Production. Agronomy, 9 (12), 888.

Surendran, U., Jayakumar, M., and Marimuthu, S. 2016. Low cost drip irrigation: Impact on sugarcane yield, water and energy saving in semiarid tropical agro ecosystem in India. Science of the Total Environment, 573, 1430-1440.

Surendran, U., Sandeep, O., and Joseph, E. J. 2016. The impacts of magnetic treatment of irrigation water on plant, water and soil characteristics. Agricultural Water Management, 178, 21-29.

Surendran, U., Sushanth, C. M., Joseph, E. J., Al-Ansari, N., and Yaseen, Z. M. 2019. FAO CROPWAT Model-Based Irrigation Requirements for Coconut to Improve Crop and Water Productivity in Kerala, India. Sustainability, 11(18), 5132.

Ucar Y., Kazaz S., Eraslan F., Baydar H. (2017): Effects of different irrigation water and nitrogen levels on the water use, rose flower yield and oil yield of Rosa damascene. Agricultural Water Management, 182: 94-102.

Walker, G.R. and Zhang, L. 2001. Plot Scale Models and Their Application to Recharge Studies. CSIRO Publishing, Melbourne

Yaghi, T., A. Arslan, F. Naoum. (2013). Cucumber (Cucumis sativus, L.) water use efficiency (WUE) under plastic mulch and drip irrigation. Agricultural WaterManagement 128 : 149- 157.

Zeng, C. Z., Bie, Z. L. and Yuan, B. Z. 2009. Determination of optimum irrigation water amount for drip-irrigated muskmelon (Cucumis melo L.) in plastic greenhouse. Agricultural Water Management, Amesterdam, v.96, n.4, p. 595-602.

\section{How to cite this article:}

Shilpa Singh, Neeraj Singh and Yogesh Pandey. 2020. Water Productivity of Vegetables Crop under Temperate Condition of Kashmir Valley. Int.J.Curr.Microbiol.App.Sci. 9(07): 31523168. doi: https://doi.org/10.20546/ijcmas.2020.907.370 